\title{
GEANT4 MODELING OF ENERGY SPECTRUM OF FAST NEUTRONS SOURCE FOR THE DEVELOPMENT OF RESEARCH TECHNIQUE OF HEAVY SCINTILLATORS
}

\author{
(D)Viktoriia Lisovska ${ }^{1}$, (D) Tetiana Malykhina ${ }^{1 *}$, \\ DValentina Shpagina ${ }^{2}$, (D) Ruslan Timchenko ${ }^{1}$ \\ ${ }^{1}$ Kharkiv V.N. Karazin National University \\ 4, Svobody sq., 61022, Kharkiv, Ukraine \\ ${ }^{2}$ National Science Center "Kharkiv Institute of Physics and Technology" \\ 1, Akademichna str., 61108, Kharkiv, Ukraine \\ *E-mail: malykhina@karazin.ua \\ Received April 14, 2019; revised June 6, 2019; accepted June 19, 2019
}

\begin{abstract}
The proposed work demonstrates the results of creating and investigating the mathematical model of the source of fast neutrons. Computer modeling of the energy spectrum of fast neutrons was carried out for ${ }^{239} \mathrm{PuBe}$ neutron source. The model of the source of fast neutrons has been developed. Neutrons in this model have an energy spectrum from $100 \mathrm{keV}$ to $11 \mathrm{MeV}$ with $100 \mathrm{keV}$ step. Simulation is performed by the Monte-Carlo method. The model carrier is a computer program developed in the C++ programming language in the Linux operating system environment, using the Geant4 toolkit. All necessary classes describing low-energy models were used for the simulation of the passage of neutrons through materials of detectors. Those take into account the elastic scattering, inelastic scattering, radiative capture and fission. We consider these processes because models of processes implemented in our software will be also used for other problems of neutrons transport, for example, for passing neutrons through various substances, and for conducting virtual laboratory works. The PhysicsList class of our program contains classes G4NeutronHPElastic, G4NeutronHPElasticData, G4NeutronHPInelastic, G4NeutronHPInelasticData, G4NeutronHPCapture, G4NeutronHPCaptureData, etc. based on the NeutronHP model for neutron interactions at low energy, as well as the neutron data library G4NDL4.5. Diagrams containing energy spectra of a source of fast neutrons modeled in two ways are presented in the paper. The analysis of the obtained energy spectra is carried out. Virtual nuclear physics experiments are carried out with the aim of testing the elaborated neutron-matter interaction model. The processes occurring in scintillator substances during the passage of fast neutrons through them, have been studied. $10^{9}$ neutrons were used as primary particles emitted isotropically, and we used our simulation results of ${ }^{239} \mathrm{PuBe}$ neutron source to describe the initial energy spectrum. The created model of ${ }^{239} \mathrm{PuBe}$ neutron source can be used for the investigation of scintillation detectors $\mathrm{Bi}_{4} \mathrm{Ge}_{3} \mathrm{O}_{12}, \mathrm{CdWO}_{4}, \mathrm{Gd}_{2} \mathrm{SiO}_{5}$ and others, as well as studying their characteristics. Processes in heavy oxide scintillators substance during the registration of fast neutrons can be studied using the developed model. It is shown that for registration of the flow of neutrons from ${ }^{239} \mathrm{PuBe}$ neutron source, using $\mathrm{Bi}_{4} \mathrm{Ge}_{3} \mathrm{O}_{12}$ or $\mathrm{CdWO}_{4}$ scintillators is more preferable. Results of the virtual nuclear physical experiments satisfy the published experimental data.
\end{abstract}

KEY WORDS: ${ }^{239}$ PuBe neutrons source, scintillation detectors, fast neutrons registration

With the aim of environmental monitoring and control of radiation hazard facilities, the devices for neutrons detection are developed by leading research centers [1]. Various classic methods are applied for registration of neutrons depending on neutrons energy. If neutrons energies exceed $10 \mathrm{MeV}$, its registration is based on the usage of compound with carbon and the study of interactions of neutrons with carbon nuclei [2]. Registration of neutrons with energies from $100 \mathrm{keV}$ to $10 \mathrm{MeV}$ is performed by scattering them on hydrogen-containing substances, and consequent registration of recoil protons.

The possibilities of detection of fast neutrons flux by heavy inorganic scintillators are investigated by scientists of V.N. Karazin Kharkiv National University in collaboration with scientists from Kharkiv Institute of Scintillation Materials [1].

In developing of devices for radiation detection, the usage of mathematical modeling allows to conduct a model experiment, and investigate the characteristics of developed detectors. The laboratory detector's experiments are carried out in harmful and dangerous working conditions due to the ionizing radiation. Computer simulation allows us to evaluate some technical parameters of the device being developed. Therefore, computer simulation is an important stage of detectors developing.

\section{FORMULATION OF THE PROBLEM}

The possibility of practical usage of heavy inorganic scintillators for neutron detection is investigated in the work [1]. However, for practical use of detectors it is necessary to estimate contributions of various mechanisms and processes that occur in the matter of these scintillators. This task can be solved using mathematical modeling and analysing its results.

The laboratory experiments were carried out with ${ }^{239} \mathrm{PuBe}$ neutron source; therefore an important phase of investigations is the development of mathematical model of the neutron radiation source. The goal of our work is computer simulation of the energy spectrum of ${ }^{239} \mathrm{PuBe}$ neutron source that will be used in programs for simulation of the passage of fast neutrons through matter. 
There are published articles $[3,4]$ where one can see the experimental energy spectra of ${ }^{239} \mathrm{PuBe}$ neutron sources. However, these data have the too wide energy step and therefore can cause significant systematic errors in virtual experiment, which use them without preliminary processing.

\section{DEVELOPING OF THE MODEL FOR FAST NEUTRONS TRANSPORT}

For study of the processes in components of the experimental facility used for fast neutrons detection, the mathematical modeling of fast neutrons passage through matter was carried out. The modeling was carried out using the Monte Carlo method.

The mathematical model is a computer program developed by our team for the simulation of passage of neutrons from ${ }^{239} \mathrm{PuBe}$ neutron source through various substances. The program developed in $\mathrm{C}++$ language with using Geant4 toolkit [5]. Description of the model includes physical and chemical properties of the materials of various facility components, its location and relative position as well as neutron source parameters. The special module contains description of neutron source. For developing of neutron source model the neutron source energy spectra from articles $[3,4]$ were digitized. Spectra in these works have the form of a histogram with wide (data from [3]) and non-uniform (data from [4]) step of energy.

For the purpose of obtaining a uniform energy step, the data was interpolated by Lagrange polynomials [6] after digitizing. Lagrange polynomial interpolation is a convenient method for such problems. The interpolation was carried out consistently with quantity of nodes from 5 to 7 . The fragmentation into smaller segments is necessary to avoid accumulation of errors in the process of interpolation [6]. The obtained data was used as input for G4PrimaryGenerator class [7], which is mandatory in each computer program based on Geant4 toolkit.

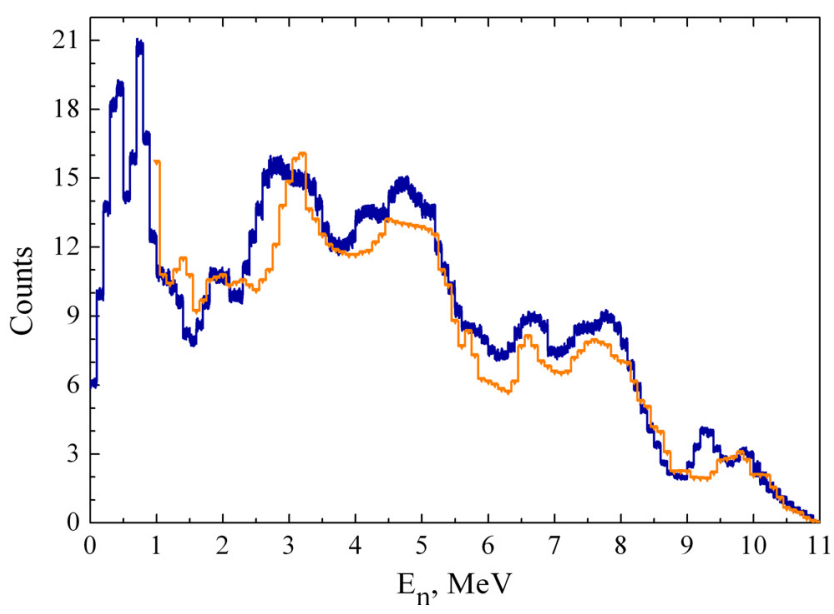

Fig. 1. The result of the G4PrimaryGenerator module: simulated neutron source spectra obtained from data [3] (light line in the chart) and [4] (dark line in the chart).
Figure 1 illustrates neutron source energy spectra modeled from two data sets [3, 4]. Energy spectra in Figure 1 were obtained as a result of the implementation of the G4PrimaryGenerator module as well as the G4GeneralParticleSource module, which uses two data sets $[3,4]$ as input data.

The G4GeneralParticleSource class [7] was applied for high-energy neutrons transport. This class allows specifying the spectral, spatial and angular distributions of primary neutrons. The flux of $10^{7}$ primary neutrons was simulated with interpolated energy spectra in order to obtain a suitable statistics. Neutrons were radiated isotropically in this model experiment.

Energy spectra of primary neutrons (Fig. 1) are results of work of G4PrimaryGenerator module, and were written in steps of $100 \mathrm{keV}$ for each sets of initial data, obtained as a result of interpolation $[3,4]$. Thus, obtained data is given to a form convenient for further use by modules of our programs.

It should be noted that spectrum of primary neutrons based on data from work [4] is more preferable for further calculations because it contains energy data of primary neutrons in the energy range from $100 \mathrm{keV}$ to $11 \mathrm{MeV}$. Unlike this energy spectrum, the spectrum based on [3] does not contain data from 100 to $1000 \mathrm{keV}$.

Our program has a user-friendly interactive mode. We have provided a number of keywords in the program, using which one can "turn on" or "turn off" some processes (previously specified in our program). For example, the command /process/inactivate/inelastic entered by the user in an interactive mode allows one "turns off" from consideration the processes of inelastic scattering.

\section{BRIEF DESCRIPTION OF PHYSICAL PROCESS MODELS AND CLASSES FOR LOW ENERGY NEUTRON TRANSPORT USED IN OUR PROGRAM}

The high-precision low energy neutron transport is implemented in corresponding classes of the Geant 4 toolkit, namely, G4NeutronHPElastic, G4NeutronHPCapture, G4NeutronHPFission, G4NeutronHPInelastic. According to [7], the cross section data for low energy neutron transport are organized in a set of files that are read in by the corresponding data set classes. The classes accessing the total cross section of the individual processes, i.e., the cross section data for high-precision low energy neutron transport, are G4NeutronHPElasticData, G4NeutronHPCaptureData, G4NeutronHPFissionData, and G4NeutronHPInelasticData [8].

The NeutronHP package in Geant4 describes high-precision neutron interactions [8] and contains information about cross sections, angular distribution of the emitted particles, energy spectra of the emitted particles, number of 
neutrons per fission, fission product yields etc., this data is placed in G4NDL4.5 files which represent Geant4 Nuclear Data Files. A detailed description of the models of these physical processes is given in $[7,8]$.

\section{SERIES OF VIRTUAL EXPERIMENTS}

In further model experiments, the opportunity of signal recording of ${ }^{239} \mathrm{PuBe}$ neutron source from distance $1000 \mathrm{~mm}$ was investigated. Initially, in real-life experiments the lead shielding was used for protection against gamma rays emitted from the ${ }^{239} \mathrm{PuBe}$ neutron source (besides neutrons). A center of this lead screen was situated at half distance to the detector, and had thickness $50 \mathrm{~mm}$. The transverse size of lead shielding was $65 \mathrm{~mm} \times 65 \mathrm{~mm}$.

Figure 2 schematically demonstrates the arrangement scheme of facility elements. The proportions of the detector are $20 \mathrm{~mm} \times 20 \mathrm{~mm} \times 20 \mathrm{~mm}$.

The first series of the virtual experiment simulated the conditions in which these practical experiments were carried out. The main aim of this virtual experiment is studying how the initial spectrum changes after passage through the lead shielding. The resulting neutrons spectrum at the distance of $1000 \mathrm{~mm}$ from ${ }^{239} \mathrm{PuBe}$ neutron source, as well as the initial spectrum, are shown in Figure 3.

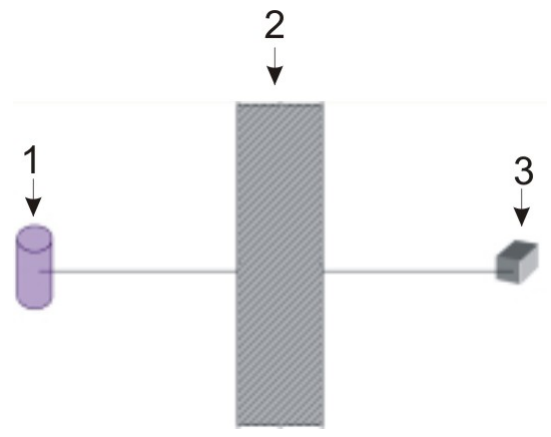

Fig.2. Arrangement scheme of facility elements in the first series of virtual experiments:

1 is neutron source; 2 is protective screen; 3 is detector

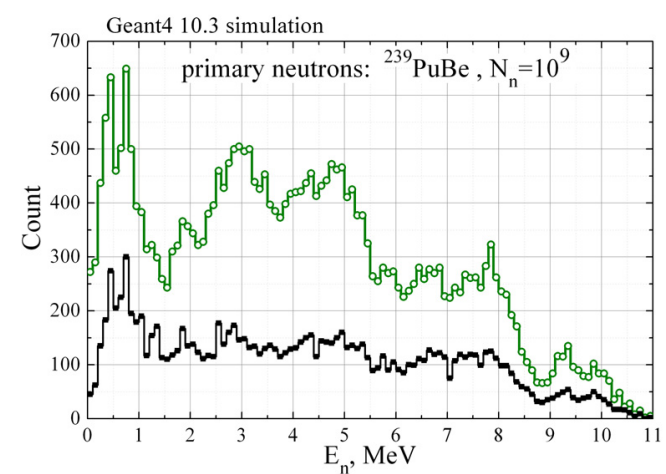

Fig. 3. Comparison of the initial neutrons spectrum (with using a protective $\mathrm{Pb}$ screen) and the result neutrons spectrum. Light line with empty circles is the initial spectrum; straight line is the result spectrum at the distance of $1000 \mathrm{~mm}$ from ${ }^{239} \mathrm{PuBe}$ neutron source

It can be seen (Fig. 3) that the general view of neutrons spectrum has been changed in energy range from $2 \mathrm{MeV}$ to $5 \mathrm{MeV}$, however the quantity of neutrons before the detector (at the distance of $1000 \mathrm{~mm}$ from the source) significantly decreased. As a result of analysis of the virtual experiment for $\mathrm{Nn}=10^{9}$ primary neutrons emitted from ${ }^{239} \mathrm{PuBe}$ neutron source, 31763 neutrons were observed before the detector without $\mathrm{Pb}$ shielding, and 11825 neutrons in case of using $\mathrm{Pb}$ shielding, this difference is explained by inelastic scattering.

The next series of virtual experiments was necessary for the development of a methodology for conducting real experiments, in which the number of neutrons detected at a distance of $1000 \mathrm{~mm}$ must be constant. Figure 4 schematically demonstrates the arrangement scheme of facility elements in the second series of virtual experiments. ${ }^{239} \mathrm{PuBe}$ neutron source is placed into a lead sphere. The radius of the sphere is $52 \mathrm{~mm}$. The distance from the neutron source to the detector is $1000 \mathrm{~mm}$.

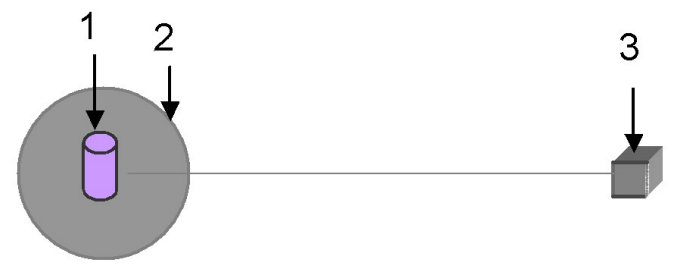

Fig.4. Arrangement scheme of facility elements in the second series of virtual experiments:

1 is neutron source; 2 is a lead sphere; 3 is detector

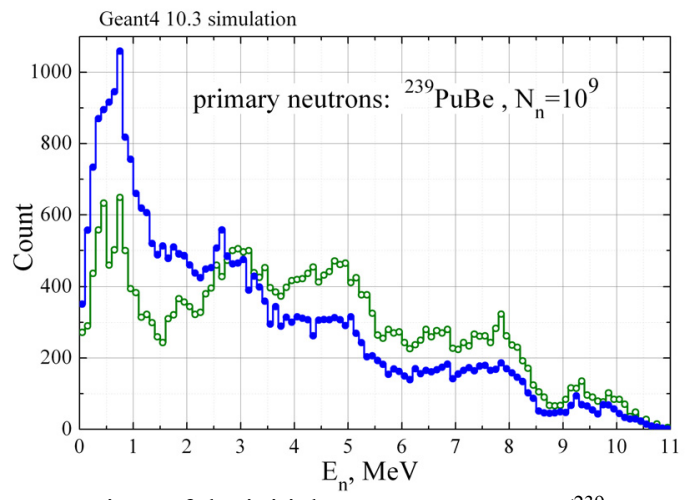

Fig. 5. Comparison of the initial neutrons spectrum $\left({ }^{239} \mathrm{PuBe}\right.$ source is into $\mathrm{Pb}$ sphere) and the result neutrons spectrum. Light line with empty circles is the initial spectrum; dark straight line is the result spectrum at the distance of $1000 \mathrm{~mm}$ from ${ }^{239} \mathrm{PuBe}$ neutron source

It can be seen (Fig. 5) that the general view of the result neutrons spectrum has been changed significantly in the energy range from $0.5 \mathrm{MeV}$ to $5 \mathrm{MeV}$, especially in the energy range $0.5-2 \mathrm{MeV}$. As a result of analysis of the second 
series of virtual experiments for $\mathrm{N}_{\mathrm{n}}=10^{9}$ primary neutrons emitted isotropically from ${ }^{239} \mathrm{PuBe}$ neutron source, 31763 neutrons were observed before the detector without the lead sphere, and 31694 neutrons in case of using the lead sphere surrounding the neutrons source.

\section{ESTIMATION OF SECONDARY GAMMA QUANTA QUANTITY}

The energy spectra of all secondary gamma quanta arising from the model experiment are shown in Fig. 6 (a).

Analyzing the simulation data, we found out that only negligible number of gamma quanta were registered by the LiI detector. It cannot affect the quality of detection of fast neutron flux. Figure 6 (b) illustrates the energy spectra of gamma quanta incoming in the detector.
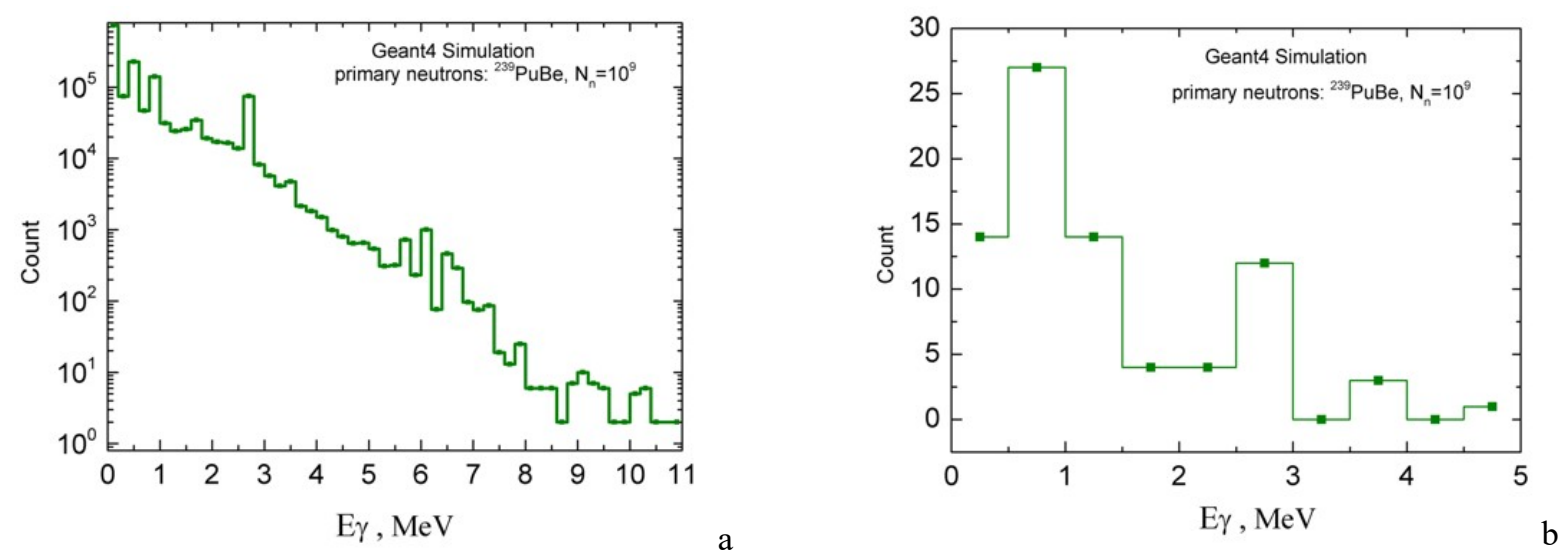

Fig. 6. Spectra of modeled secondary gamma quanta:

(a) is spectrum for all gamma quanta; (b) is spectrum for incoming in detector gamma quanta

The total number of secondary gamma quanta produced in the process of model experiment is about $1.5 \times 10^{7}$, while the number of gamma quanta registered by detector is 79 .

The further laboratory tests confirmed the opportunity of applying heavy inorganic scintillators of small size for fast neutron flux registration from ${ }^{239} \mathrm{PuBe}$ neutron source.

\section{COMPARISON OF RESULTS WITH PUBLISHED DATA}

Experimental measurements and analysis of detection efficiency were carried out for fast neutrons from ${ }^{239} \mathrm{PuBe}$ neutron source using oxide scintillators: $\mathrm{Bi}_{4} \mathrm{Ge}_{3} \mathrm{O}_{12}, \mathrm{CdWO}_{4}, \mathrm{Gd}_{2} \mathrm{SiO}_{5}$ as well as $\mathrm{CsI}(\mathrm{Tl}), \mathrm{NaI}(\mathrm{Tl})$, $\mathrm{LiI}(\mathrm{Eu})$ [9]. Fast neutrons registration efficiencies obtained experimentally [9] by heavy inorganic oxide scintillators $(Z>50)$ that have the same size, reach values from 42 to 48 percent and presented in Table 1. Results of measurements of the neutron fluxes registration efficiency by different scintillators in the equivalent energy range for electrons (gamma-quanta) of 20-300 keV [9] are presented in the right column of the Table 1.

Inelastic scattering reaction (n, n' $\gamma$ ) is a one of reliable mechanisms providing a high efficiency of fast neutron detection [7] by oxide scintillators. Figure 7 demonstrates modeled values of deposited energy in detectors.

Table 1.

Efficiency of fast neutron registration, \% [9]

\begin{tabular}{|c|c|c|}
\hline $\begin{array}{c}\text { Scintillator } \\
\text { (monocrystalline } \\
\text { solid) }\end{array}$ & $\mathrm{Z}_{\mathrm{eff}}$ & $\begin{array}{c}\text { Efficiency of fast } \\
\text { neutron registration, } \\
\%\end{array}$ \\
reaction $\left(\mathrm{n}, \mathrm{n}^{\prime} \gamma\right)$
\end{tabular}

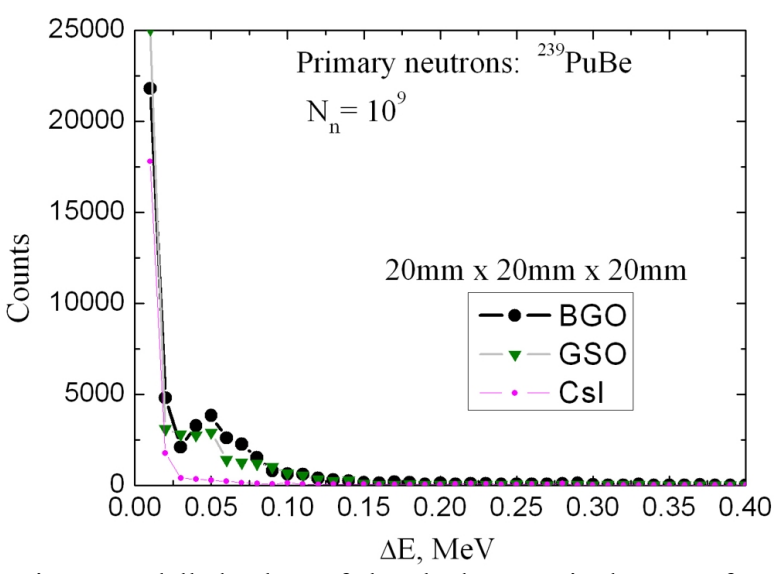

Fig. 7. Modelled values of absorbed energy in detectors for BGO, GSO, and CsI.

Small peaks are visible at $\Delta \mathrm{E} \approx 0.05 \mathrm{MeV}$ for BGO and GSO scintillators. As a result of this analysis, the maximum peak value is 3830 , therefore the statistical uncertainty of the Monte Carlo method is $1 / \sqrt{3830} \approx 0.016$. This statistical uncertainty is acceptable for preliminary and estimational calculations. 
Using preliminary virtual experiments, one can study mechanisms and reactions occurring in matter of scintillators during the registration of fast neutrons.

\section{CONCLUSION}

As a result of this work, the characteristics of the neutron source have been modeled and used for the study of response of scintillator detectors to neutron flux of ${ }^{239} \mathrm{PuBe}$ neutron source.

The convenient form of representation of fast neutrons energy spectrum from ${ }^{239} \mathrm{PuBe}$ neutron source has been obtained for use in computer programs for analyzing the characteristics of scintillators.

It is shown that the model based on data [4] is more preferable for further usage, because it contains neutrons with energies below $1 \mathrm{MeV}$ in the initial spectrum. This is significant for neutron flux detection by heavy inorganic scintillators $\left(\mathrm{Bi}_{4} \mathrm{Ge}_{3} \mathrm{O}_{12}, \mathrm{CdWO}_{4}, \mathrm{Gd}_{2} \mathrm{SiO}_{5}\right.$ and others).

It is proposed to improve the methodology for conducting experiments for studying the response of heavy oxide scintillators by providing preliminary virtual experiments.

Based on conducted research, it can be concluded that heavy oxide scintillators, which at the same time are efficient gamma-detectors [9], allow to create highly efficient gamma-neutron detectors that provide high efficiency of fissile radioactive materials detection.

\section{ORCID IDs}

Viktoriia Lisovska@https://orcid.org/0000-0003-1237-7959, Tetiana Malykhina@https://orcid.org/0000-0003-0035-2367, Valentina Shpagina @https://orcid.org/0000-0002-6202-7474, Ruslan Timchenko@https://orcid.org/0000-0003-4983-9168

\section{REFERENCES}

[1]. V.D. Ryzhikov, B.V. Grinyov, G.M. Onyshchenko, L.A. Piven, S.V. Naydenov and O.K. Lysetska, Functional Materials, 3(21), 345-351 2014, doi: 10.15407/fm21.03.345.

[2]. Neutron interaction with matter, in http://nuclphys.sinp.msu.ru/partmat/pm04.htm.

[3]. M.E. Anderson and R.A. Neff, Nuclear Instruments and Methods, 99(2), 231-235 1972, doi: 10.1016/0029-554X(72)90781-1.

[4]. G.I. Britvich, V.G. Vasil'chenko, Yu.V. Gilitsky, A.P. Chubenko, A.E. Kushnirenko, E.A. Mamidzhanyan, V.P. Pavlyuchenko,V.A. Pikalov, V.A. Romakhin, A.P. Soldatov, O.V. Sumaneev, S.K. Chernichenko, I.V. Shein and A.L. Shepetov, Instruments and Experimental Techniques, 47, (5), 571-584 2004, doi: 10.1023/B:INET.0000.

[5]. J. Allison, K. Amako, J. Apostolakis, P. Arce, M. Asai, T. Aso, E. Bagli, A. Bagulya, S. Banerjee, G. Barrand, B.R. Beck, A.G. ogdanov, D. Brandt, J.M.C. Brown, H. Burkhardt, Ph. Canal, D. Cano-Ott, S. Chauvie, K. Cho, G.A.P. Cirrone, G. Cooperman, M.A. Cortés-Giraldo, G. Cosmo, G. Cuttone, G. Depaola, L. Desorgher, X. Dong, A. Dotti, V.D. Elvira, G. Folger, Z. Francis, A. Galoyan, L. Garnier, M. Gayer, K.L. Genser, V.M. Grichine, S. Guatelli, P. Guèye, P. Gumplinger, A.S. Howard, I. Hřivnáčová, S. Hwang, S. Incerti, A. Ivanchenko, V.N. Ivanchenko, F.W. Jones, S.Y. Jun, P. Kaitaniemi, N. Karakatsanis, M. Karamitros, M. Kelsey, A. Kimura, T. Koi, H. Kurashige, A. Lechner, S.B. Lee, F. Longo, M. Maire, D. Mancusi, A. Mantero, E. Mendoza, B. Morgan, K. Murakami, T. Nikitina, L. Pandola, P. Paprocki, J. Perl, I. Petrović, M.G. Pia, W. Pokorski, J.M. Quesada, M. Raine, M.A. Reis, A. Ribon, A. Ristić Fira, F. Romano, G. Russo, G. Santin, T. Sasaki, D. Sawkey, J.I. Shin, I.I. Strakovsky, A. Taborda, S. Tanaka, B. Tomé, T. Toshito, H.N. Tran, P.R. Truscott, L. Urban, V. Uzhinsky, J.M. Verbeke, M. Verderi, B.L. Wendt, H. Wenzel, D.H. Wright, D.M. Wright, T. Yamashita, J. Yarba and H. Yoshida, Nuclear Instruments and Methods in Physics Research, 835, 186-225 2016, doi: 10.1016/j.nima.2016.06.125.

[6]. W. Press, S. Teukolsky, W. Vetterlong and B. Flannery, editors, Numerical Recipes: The Art of Scientific Computing (Cambridge University Press, 2007), http://www.cambridge.org.

[7]. Geant4 User's Guide for Application Developers (CERN, 2018), in: http://cern.ch/geant4-userdoc/ UsersGuides/ForApplicationDeveloper/fo/BookForApplicationDevelopers.pdf

[8]. Geant4 Physics Reference Manual (CERN, 2018), in: http://cern.ch/geant4-userdoc/UsersGuides/ PhysicsReferenceManual/fo/PhysicsReferenceManual.pdf

[9]. Наука про матеріали: досягнення та перспективи. Том 1, [Material Science: Achievements and Prospects. Volume 1], (Akademperiodyka, Kyiv, 2018), pp. 652.

\section{GEANT4-МОДЕЛЮВАННЯ ЕНЕРГЕТИЧНОГО СПЕКТРУ ДЖЕРЕЛА ШВИДКИХ НЕЙТРОНІВ ДЛЯ НАПРАЦЮВАННЯ МЕТОДИКИ ДОСЛІДЖЕННЯ ВАЖКИХ СЦИНТИЛЯТОРІВ В.В.Лісовська ${ }^{1}$, Т.В. Малихіна ${ }^{1}$, В.О. Шпагіна ${ }^{2}$, Р.М. Тимченко ${ }^{1}$ \\ ${ }^{1}$ Харківський національний університет імені В.Н. Каразіна майдан Свободи, 4, 61022, Харків, Україна \\ ${ }^{2}$ Національний науковий иентр Харківський фізико-технічний інститут вул. Академічна, 1, 61108, Харків, Украӥна}

В роботі представлені дослідження математичної моделі джерела швидких нейтронів. Проведено комп'ютерне моделювання енергетичного спектру швидких нейтронів від джерела ${ }^{239} \mathrm{PuBe}$. Розроблено модель джерела, що має енергетичний спектр нейтронів з кроком 100 кеВ у діапазоні енергій від 100 кеВ до $11 \mathrm{MeB.} \mathrm{Моделювання} \mathrm{проведено}$ методом Монте-Карло. Носієм моделі $\epsilon$ комп'ютерна програма, розроблена мовою програмування $\mathrm{C}++$ в середовищі операційної системи Linux з використанням бібліотеки класів Geant4. При моделюванні проходження нейтронів через речовини детекторів використовувалися всі необхідні класи, що містять моделі низьких енергій, і враховувалися процеси радіаційного захоплення, пружного розсіювання, поділу, непружного розсіювання, тому що програмно описані моделі процесів передбачається використовувати і для інших завдань, наприклад, проходження нейтронів через різні речовини, а 
також для проведення віртуальних лабораторних рабіт. При описі фізичних процесів у модулі PhysicsList poзробленої програми використовувалися класи бібліотеки Geant4 G4NeutronHPElastic, G4NeutronHPElasticData, G4NeutronHPInelastic, G4NeutronHPInelasticData, G4NeutronHPCapture, G4NeutronHPCaptureData тощо, які засновані на модулях у складі пакету NeutronHP, і бібліотеки нейтронних даних G4NDL4.5. Представлені графіки, що містять змодельовані двома способами енергетичні спектри джерела швидких нейтронів ${ }^{239} \mathrm{PuBe}$. Проведено аналіз отриманих енергетичних спектрів. Для тестування моделі взаємодії нейтронів з речовиною проведені віртуальні ядерно-фізичні експерименти і досліджені процеси, що відбуваються у речовинах сцинтиляторів при проходженні через них потоку швидких нейтронів. У якості первинних частинок використовувалися $10^{9}$ нейтронів з енергетичним спектром, отриманим в результаті моделювання ${ }^{239} \mathrm{PuBe}$ джерела нейтронів, і випромінюваних ізотропно. Розроблена модель ${ }^{239} \mathrm{PuBe}$ джерела нейтронів призначена для дослідження відгуку сцинтиляційних детекторів $\mathrm{Bi}_{4} \mathrm{Ge}_{3} \mathrm{O}_{12}, \mathrm{CdWO}_{4}, \mathrm{Gd}_{2} \mathrm{SiO}_{5}, \mathrm{CsI}$ та ін. на потік швидких нейтронів, а також дослідження важливих характеристик детекторів. У результаті проведення віртуальних ядерно-фізичних експериментів показано, що для реєстрації потоку нейтронів від джерела ${ }^{239} \mathrm{PuBe}$ більш перспективним є використання сцинтиляторів $\mathrm{Bi}_{4} \mathrm{Ge}_{3} \mathrm{O}_{12}$ або $\mathrm{Gd}_{2} \mathrm{SiO}_{5}$. Результати віртуальних ядерно-фізичних експериментів знаходяться у відповідності до опублікованих експериментальних даних.

КЛЮЧОВІ СЛОВА: ${ }^{239} \mathrm{PuBe}$ джерело нейтронів, сцинтиляційні детектори, реєстрація швидких нейтронів

\section{GEANT4-МОДЕЛИРОВАНИЕ ЭНЕРГЕТИЧЕСКОГО СПЕКТРА ИСТОЧНИКА БЫСТРЫХ НЕЙТРОНОВ ДЛЯ НАРАБОТКИ МЕТОДИКИ ИССЛЕДОВАНИЯ ТЯЖЕЛЫХ СЦИНТИЛЛЯТОРОВ В.В. Лисовская ${ }^{1}$, Т.В. Малыхина ${ }^{1}$, В.О. Шпагина ${ }^{2}$, Р.М. Тимченко ${ }^{1}$ \\ ${ }^{1}$ Харьковский национальный университет имени В.Н. Каразина майдан Свободы, 4, 61022, Харьков, Украина \\ ${ }^{2}$ Национальный научный центр Харьковский физико-технический институт ул. Академическая, 1, 61108, Харьков, Украина}

В работе представлены исследования математической модели источника быстрых нейтронов. Проведено компьютерное моделирование энергетического спектра быстрых нейтронов от источника ${ }^{239} \mathrm{PuBe}$. Разработана модель источника, имеющая энергетический спектр нейтронов с шагом 100 кэВ в диапазоне энергий от 100 кэВ до 11 МэВ. Моделирование проведено методом Монте-Карло. Носителем модели является компьютерная программа, разработанная на языке программирования $\mathrm{C}++$ в среде операционной системы Linux с использованием библиотеки классов Geant4. При моделировании прохождения нейтронов через вещества детекторов использовались все необходимые классы, содержащие модели низких энергий, и учитывались процессы радиационного захвата, упругого рассеяния, деления, неупругого рассеяния, так как программно описанные модели процессов предполагается использовать и для других задач, например, прохождения нейтронов через различные вещества, а также для проведения виртуальных лабораторных работ. При описании физических процессов в модуле PhysicsList разработанной программы использовались классы библиотеки Geant4 G4NeutronHPElastic, G4NeutronHPElasticData, G4NeutronHPInelastic, G4NeutronHPInelasticData, G4NeutronHPCapture, G4NeutronHPCaptureData и др., основанные на модулях в составе пакета NeutronHP, и библиотеки нейтронных данных G4NDL4.5. Представлены графики, содержащие смоделированные двумя способами энергетические спектры источника быстрых нейтронов ${ }^{239} \mathrm{PuBe}$. Проведен анализ полученных энергетических спектров. Для тестирования модели взаимодействия нейтронов с веществом проведены виртуальные ядерно-физические эксперименты и исследованы процессы, происходящие в веществах сцинтилляторов при прохождении через них потока быстрых нейтронов. В качестве первичных частиц использовались $10^{9}$ нейтронов с энергетическим спектром, полученным в результате моделирования ${ }^{239} \mathrm{PuBe}$ источника, и излучаемых изотропно. Разработанная модель источника ${ }^{239} \mathrm{PuBe}$ предназначена для исследования отклика сцинтилляционных детекторов $\mathrm{Bi}_{4} \mathrm{Ge}_{3} \mathrm{O}_{12}, \mathrm{CdWO}_{4}, \mathrm{Gd}_{2} \mathrm{SiO}_{5}$, CsI и др. на поток быстрых нейтронов, а также исследования различных характеристик детекторов. В результате проведения виртуальных ядерно-физических экспериментов показано, что для регистрации потока нейтронов от источника ${ }^{239} \mathrm{PuBe}$ более предпочтительным является использование сцинтилляторов $\mathrm{Bi}_{4} \mathrm{Ge}_{3} \mathrm{O}_{12}$ или $\mathrm{Gd}_{2} \mathrm{SiO}_{5}$. Результаты виртуальных ядерно-физических экспериментов находятся в хорошем соответствии с опубликованными экспериментальными данными.

КЛЮЧЕВЫЕ СЛОВА: ${ }^{239} \mathrm{PuBe}$ источник нейтронов, сцинтилляционные детекторы, регистрация быстрых нейтронов 